\title{
Stabilized mortar with air incorporator agent and plasticizer set retarder: performance measurement
}

\section{Desempenho de argamassa estabilizada com aditivo incorporador de ar e plastificante retardador de pega}
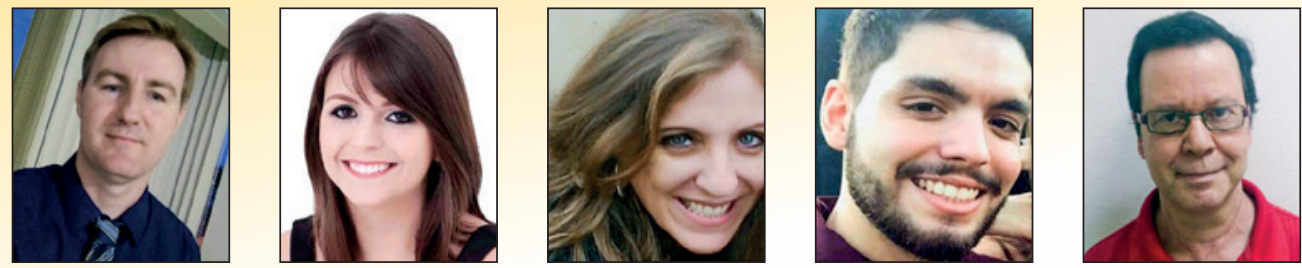

A. SCHACKOW ${ }^{\text {a }}$

adilson.schackow@udesc.br https://orcid.org/0000-0003-2561-5231

\begin{tabular}{|c|}
\hline $\begin{array}{r}\text { A. K. FERRARI a } \\
\text { anakaroliny 3@hotmail.com } \\
\text { https://orcid.org/0000-0003-4376-2374 }\end{array}$ \\
\hline $\begin{array}{r}\text { C. EFFTING a } \\
\text { carmeane.effting@udesc.br } \\
\text { https://orcid.org/0000-0001-5457-5457 }\end{array}$ \\
\hline $\begin{array}{r}\text { V. O. ALVES a } \\
\text { vitoralves18@gmail.com } \\
\text { https://orcid.org/0000-0002-4830-3006 }\end{array}$ \\
\hline \\
\hline
\end{tabular}

https://orcid.org/0000-0002-2663-9123

\begin{abstract}
This study aims to develop three stabilized mortars to masonry using air entraining agents and settling retardant plasticizer to compare with a conventional mortar with lime. It was analyzed consistency index, specific gravity, air entrained content, water retentivity, setting time through the heat of hydration, mortar shrinkage/expansion, compressive strength, resistance to sulphate and tensile strength in bonding. The results exhibited that the presence of the settling retardant plasticizer affected the consistency index making the mortar more workable for a longer time. The presence of additives made the stabilized mortars lighter with lower mass density and higher incorporated air content. The presence of lime provided high water retentivity in the conventional mortar while the setting retardant plasticizer improved the water retentivity in the stabilized mortars. The initial setting time of the stabilized mortars occurred after approximately 50 hours. Conventional mortar lost its workability quickly after 2 hours. In conventional mortar, shrinkage occurred, while stabilized mortars had expansion. The conventional mortar exhibited better compressive strength, while the excess of additives can affected negatively this property in the stabilized mortars. Conventional mortar proved to be less resistant to sulphate attack. Tensile strength in bonding was better in a stabilized commercial mortar tested.
\end{abstract}

Keywords: stabilized mortar, brickwork and masonry, materials technology, sustainability.

\section{Resumo}

Este estudo tem como objetivo desenvolver três argamassas estabilizadas para alvenaria com aditivo incorporador de ar e plastificante retardador de pega para comparar com uma argamassa convencional com cal. Foi analisado o índice de consistência, a massa específica, o teor de ar incorporado, a retenção da água, o tempo de pega através do calor de hidratação, a retração/expansão da argamassa, a resistência à compressão, a resistência ao sulfato e a resistência de aderência à tração. Os resultados mostraram que a presença do plastificante retardador de pega afetou o índice de consistência, tornando a argamassa trabalhável por mais tempo. A presença de aditivos tornou as argamassas estabilizadas mais leves, com menor densidade e maior teor de ar incorporado. A presença da cal proporcionou alta retenção de água na argamassa convencional, enquanto o plastificante retardador de pega melhorou a retenção de água nas argamassas estabilizadas. O tempo inicial de pega das argamassas estabilizadas ocorreu após aproximadamente 50 horas. A argamassa convencional perdeu sua trabalhabilidade rapidamente após 2 horas. $\mathrm{Na}$ argamassa convencional, ocorreu retração, enquanto que nas argamassas estabilizadas houve expansão. A argamassa convencional apresentou melhor resistência à compressão, enquanto que o excesso de aditivos pode ter afetado negativamente essa propriedade nas argamassas estabilizadas. A argamassa convencional mostrou-se menos resistente ao ataque por sulfato. A resistência de aderência à tração foi melhor na argamassa comercial estabilizada testada.

Palavras-chave: argamassa estabilizada, alvenaria, tecnologia de materiais, sustentabilidade.

State University of Santa Catarina, Center of Technological Sciences, Department of Civil Engineering, Joinville, SC, Brazil.

Received: 06 Dec 2017 • Accepted: 02 Nov 2018 • Available Online:

ॠलm This is an open-access article distributed under the terms of the Creative Commons Attribution License 


\section{Introduction}

The stabilized mortar is an industrialized damp cement-based mortar that is ready for use and remains workable for up to 72 hours after it is made. To promote the retardation of the handle setting time, the manufacturers introduce retarding additives and air incorporator so that their characteristics are preserved for a predefined period of time.

In an engineering project, mainly in the implementation phase of the enterprise, the mortar is considered one of the most wasted items, influencing the workers' productivity and the waste generated. Therefore, the development of a stabilized mortar that is workable for a longer time, that reduces waste and that improves productivity can be an alternative (Shmid, 2011 [1]).

In order to promote increased duration of the handle setting time, Carasek (2010) [2] states that hydration inhibiting additives and air incorporator additives are used to give the mortar better workability and reduction of kneading water. Companies that market stabilized mortar indicate that a layer of water up to $1 \mathrm{~cm}$ should be maintained on the surface of the product when it is not being used, thus avoiding a decrease in stability.

The stabilized mortar is dosed in plants, transported and mixed in concrete mixer trucks, similarly to machined concretes. After arriving on the work, it is stored in specific containers of about 250-350 liters (Paulo, 2006 [3]). The mortar should not be exposed to sunshine, wind or other conditions that cause premature water loss. In addition, as it is additivated, Carasek (2010) [2] emphasizes the importance of the mixing time and the air content of the mortar which must be controlled, thus providing the quality of the product. Stabilized mortar can be used for laying, plaster and parget, regularization of floors and waterproofing, among other uses.

Macioski (2014) [4] points out that much of the literature on this mortar deals with the advantages of stabilized mortar in the process of work productivity, and that there are few studies that go much deeper into technical aspects of material evaluation and dosage studies. Suppliers, in turn, do not disclose any information about product development, stating only that it meets current standards. Thus, there are practically no published articles presenting technical aspects and dosage studies of stabilized mortar. Thus, this study aims to contribute by disclosing the results found in a series of experiments in stabilized mortars seeking to measure characteristics such as consistency index, water retentivity, setting time, compressive strength, dimensional charges, sulphate attack, among others.

This dimensional variation depends on several parameters such as concrete composition, quality of its components, size of elements and curing conditions (Itim et al., 2011 [5]). There are several studies on retraction in mortars, including several types of residues, such as flywheels, ceramics, construction waste, glass, among others (Itim et al., 2011 [5], Zhang et al., 2015 [6], Messan et al., 2011 [7], Cheah and Ramli, 2012 [8], Hasegawa et al., 2014 [9]). But there are no studies showing the retraction/expansion of mortars stabilized as presented in this study. A recent study (Fujiwara et al., 2017 [10]) showed that using urea solution to soak mortar could reduce drying shrinkage. When the urea solution concentration is higher, the effect is better. The study also showed that the application of water (spray) worsens the retraction in relation to not applying anything at all.

Conductive microcalorimetry is a powerful tool to investigate the kinetic properties of rapid chemical reactions and physical processes involving considerable thermal changes, and it has achieved wide application in many fields (Pytel, 2004 [11], Lootens and Bentz, 2016 [12]). The physical properties of a hydrating paste also influence the setting when it occurs (Watts and Ferraro, 2017 [13]). The water to cement ratio has the greatest effect, since the amount of water is reduced, the distance between particles and the time required for them to become interconnected decrease (Sant et al., 2009 [14]). The size of the particles also influence the rate at which hydration progresses; a fine particle size increases the available surface area for reaction to occur, thus accelerating the setting set (Neville, 2016 [15], Zhang et al., 2013 [16], Wenk, 2008 [17]).

The stabilized mortar, already dosed in central, needs no place for storage of the constituent materials. No labor is required for production at the work. For Silva (2008) [18], as they are products that already come with a technological control of the factory, there are less chances of committing errors of dosage and waste of materials in the construction site, which directly affects the quality and the final cost of the enterprise.

For this type of mortar, greater planning is required, since it is necessary to schedule deliveries, storage at the work and application.

\section{Materials and experimental program}

Portland cement CP II Z-32 (Brazilian Portland Cement Society) was used, Table 1. Four types of sand from the Northern Region of Santa Catarina State rivers (Brazil) were previously determined. Features such as granulometry (fineness modulus, maximum diameter), specific mass and unit mass of the four types of sands were evaluated. Thus, the most suitable sand to be used in stabilized mortar for the execution of the mixtures was determined. A previous study used sand with a fineness modulus of 1.68 for stabilized mortar [19]. Manufacturers of stabilized mortar additives also recommend fineness modulus of about 1.7 for sand. Thus, the studied sand 1 was chosen to perform all the mixtures of this study, since it presented fineness modulus of 1.75 .

Two types of chemical additives were used: An air incorporator additive for mortar dosed in central and a handle retarder plasticizer

\section{Table 1}

\section{Chemical composition of Portland cement}

\begin{tabular}{cc}
\cline { 2 - 2 } & $\begin{array}{c}\text { Chemical composition } \\
\text { (wt. \%) } \\
\text { CP II - } \mathbf{~ - ~ 3 2 ~}\end{array}$ \\
$\mathrm{Al}_{2} \mathrm{O}_{3}$ & 6.77 \\
$\mathrm{CaO}$ & 52.79 \\
$\mathrm{Fe}_{2} \mathrm{O}_{3}$ & 3.15 \\
$\mathrm{MgO}$ & 4.15 \\
$\mathrm{SiO}_{2}$ & 22.41 \\
$\mathrm{SO}_{3}$ & 2.79 \\
$\left(\mathrm{~K}_{2} \mathrm{O}+\mathrm{Na}_{2} \mathrm{O}\right)^{*}$ & 0.78 \\
Loss on ignition & 5.00 \\
\hline
\end{tabular}

* Alkali equivalent, which can form expansive compounds 
Table 2

Specifications of the additives used

\begin{tabular}{ccc}
\hline Parameters & $\begin{array}{c}\text { Air entraining } \\
\text { agent }\end{array}$ & $\begin{array}{c}\text { Plasticizer } \\
\text { set retarder }\end{array}$ \\
\hline Appearance & Liquid & Liquid \\
Color & Brown reddish & Brown reddish \\
pH at $25^{\circ} \mathrm{C}$ & 10.62 & 7.16 \\
Specific weight & 1.01 & 1.17 \\
$\left(\mathrm{~g} / \mathrm{cm}^{3}\right)$ & 5.03 & 38.52 \\
Solids content $(\%)$ &
\end{tabular}

additive for mortar dosed in central. Table 2 contains technical data for each additive supplied by the manufacturer.

The lime used in the application of conventional mortar was the hydrated type $\mathrm{CH}-\mathrm{III}$ (Brazilian Association for Technic Standards). Table 3 presents some features provided by the manufacturer. The water used was obtained by the local water company at a temperature of approximately $23^{\circ} \mathrm{C}$.

Hermann and Rocha (2013) [19] used mixtures with a ratio of 1: 5.75 in their study. Keller and Lovato (2016) [20] used mixtures with a ratio of 1: 4.5. Both studies have found results that may be considered adequate considering their application and mechanical strength. Thus, for the study of stabilized mortar for ceramic masonry laying, three mixtures were prepared: $1: 6$ (cement: sand, by volume) using $0.5 \%$ air incorporator additive and $0.8 \%$ handle retarder plasticizer additive, $1: 6$ with $0.5 \%$ air incorporator additive and $1.5 \%$ handle retarder plasticizer additive, and also $1: 4.5$ with $0.5 \%$ air-incorporator additive and $0.8 \%$ handle retarder plasticizing additive.

For comparison, a conventional mortar with $1: 1.5: 6$ mixture (cement: lime: sand) was also made. From this was used the mixture by mass, of $1: 1.042: 8$, without adding additives. The chosen water/cement factor was 1.6. The used sand moisture was $5.5 \%$. To measure the stabilized mortar, the same procedure was followed as for conventional mortar, converting from volume to mass, removing the lime and adding the additives. The amount of materials used in each mixture is given in Table 4.

\subsection{Tests performed on fine aggregates}

For the determination of the granulometric composition, the stan-
Table 3

Physical and chemical characteristics of the lime CHIII

\begin{tabular}{cc}
\hline Characteristic & Result (\%) \\
\hline Loss on fire & 24.1 \\
Total oxides (CaO + MgO) & 96.0 \\
Carbon dioxide anhydride $\mathrm{CO}_{2}$ & 5.6 \\
Non-hydrated total oxides & 14.5 \\
Granulometry \# $30(0.60 \mathrm{~mm})$ & 0.0 \\
Granulometry \# $200(0.075 \mathrm{~mm})$ & 12.0 \\
Humidity & 0.0 \\
\hline
\end{tabular}

dard NBR NM 248 (ABNT, 2003 [21]) was used. The Maximum Characteristic Dimension (MCD) and the Fineness Module (FM) were determined. The specific mass of the aggregates was determined as per NBR NM 52 (ABNT, 2009 [22]).

\subsection{Tests performed on mortars}

The preparation of the mortar was as per NBR 16541 (ABNT, 2016a [23]).

The determination of the consistency index was determined following the specifications of NBR 13276 (ABNT, 2016b [24]). The purpose of this test is to evaluate the workability of the mortar. After the mortar was prepared, the frustoconical was filled in three successive layers, with approximately equal heights and 15, 10 and 5 strokes being applied with the socket. The shadings of the mortar in the frustoconical were made with a metallic ruler. The mold was removed and then the crank of the table was activated so that the table would fall 30 times in 30 seconds evenly. Then, the mortar spreading on the table was measured with a pachymeter. Three measurements of the diameter were recorded. The mean of the three measurements expressed in millimeters is the consistency index.

The mass density and the incorporated air content were determined following NBR 13278 (ABNT, 2005b [25]). Immediately after its preparation, a rigid cylindrical vessel with volume of $400 \mathrm{~cm}^{3}$ was molded into three uniform layers. Twenty blows were applied on the mortar along its perimeter in the vessel. After filling, three drops of the container with a height of approximately $3 \mathrm{~cm}$ were made so that there were no voids between the mortar and the wall of the container. Finally, the bowl was scraped with a spatula, with

\section{Table 4}

Fresh mortars formulations

\begin{tabular}{ccccc}
\hline $\begin{array}{c}\text { Mixture components } \\
\text { (to produce about 2.5 liters) }\end{array}$ & Convencional mortar & Stabilized mortar 1 & Stabilized mortar 2 & Stabilized mortar 3 \\
\hline In volume & $1: 1.5: 6$ & $1: 6$ & $1: 6$ & $1: 4.5$ \\
In mass & $1: 1.042: 8$ & $1: 8$ & $1: 8$ & $1: 6$ \\
Portland cement (g) & 414.87 & 414.87 & 414.87 & 414.87 \\
Lime (g) & 432.29 & - & - & - \\
Sand (g) & 3318.96 & 3318.96 & 3318.96 & 2489.22 \\
Water* (g) & 661.59 & 373.38 & 269.25 & 203.56 \\
Air entraining agent (g) & - & $2.07(0.5 \%)$ & $2.07(0.5 \%)$ & $2.07(0.5 \%)$ \\
Setting retardant plasticizer (g) & - & $3.32(0.8 \%)$ & $6.22(1.5 \%)$ & $3.32(0.8 \%)$ \\
Water to cement ratio & 1.60 & 0.90 & 0.65 & 0.50 \\
\hline
\end{tabular}

* Considering sand humidity of $5.5 \%$ wt. 
back-and-forth movements. After this procedure, the mold mass was weighed. The density calculation was then calculated by equation 1 :

$d=\frac{M_{c}-M_{v}}{V_{t}} \times 100$

Where: $M c=$ mass of the cylindrical vessel with mortar (in grams); $M v=$ mass of the empty cylindrical vessel (in grams); $v t=$ volume of the cylindrical vessel (in $\mathrm{cm}^{3}$ ).

Then, the content of air incorporated in the mortar was calculated in percentage by equation 2 .

$A=\left(1-\frac{d}{d_{t}}\right) \times 100$

Where: $d=$ density of the mortar (in $\mathrm{cm}^{3}$ ); $d t=$ theoretical density of the mortar (in $\mathrm{cm}^{3}$ ).

The water retention capacity of each mortar was measured as per NBR 13277 (ABNT, 2005a [26]). The mortar was placed in a paper filter dish over the Buchner funnel and a suction force of $51 \mathrm{mmHg}$ was applied to the assembly with the aid of an electric motor for 15 minutes. The water retention capacity $(\mathrm{Ra})$ was measured through equations 3 and 4 .

$R_{a}=\left[1-\frac{\left(m_{a}-m_{s}\right)}{A F\left(m_{a}-m_{v}\right)}\right]$

$A F=\frac{m_{w}}{m+m_{w}}$

Where $m_{a}$ is the mass of the joint with mortar; $m_{s}$ is the mass of the assembly after suction; $m_{v}$ is the mass of the empty assembly; $A F$ is the water / fresh mortar factor; $m_{w}$ is the total mass of water added to the mixture, in grams; $m$ is the sum of the masses of the anhydrous components, in grams.

Handle duration analysis is very important for stabilized mortar, as the longer working time (which is actually the purpose of this mortar)

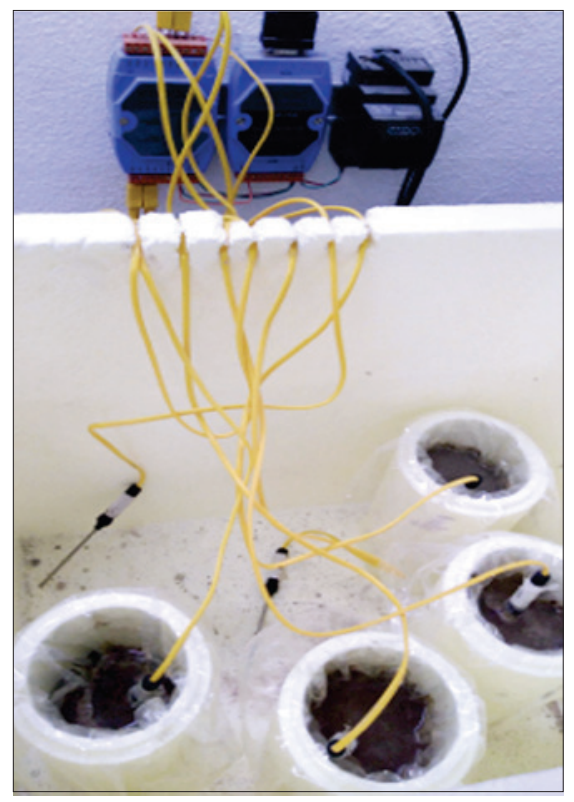

Figure 1

Mortar samples during calorimeter test can be measured by the heat of hydration of the cement in the mixture. Handling time can be measured by the method of penetrating a needle into the paste or by the cement hydration heat. In this study, a calorimeter in a semi-adiabatic method was used through the monitoring of temperatures by duration. The data acquired by the calorimetry test defines the behavior of the evaluated material for the setting and end time of handle. The purpose of the test is to evaluate the performance of mortars due to their variable amount of handle retardant additive. The amount of mortar used was enough to fill an EPS container with volume of $1 \mathrm{dm}^{2}$ able to accommodate the calorimeter receivers. This container was placed inside a larger EPS box $\left(40 \times 40 \times 50 \mathrm{~cm}^{3}\right)$ to simulate a semi-adiabatic condition. The calorimetry apparatus has eight sample inlet channels, equipped with thermocouples at its ends (Figure 1). The k-type thermocouples were connected at a calorimeter model IP-7018 and the software Impaclog 08 was used. The error of the temperatures measured was $0.05 \%$.

The determination of the start and end time of handle were established due to the temperature variation of the mortar presented by the calorimetric curve and numerical values generated from the software data. The mortars remained in the equipment for up to 2 days. The stabilized mortars received a $1 \mathrm{~cm}$ film of water on the surface to remain in the stabilized state. The temperature inside the laboratory remained at $23^{\circ} \mathrm{C}$ (with air conditioner connected intermittently) so that there was no great variation of temperature due to the environment outside the box where the samples were located.

The determination of the dimensional variation of the mortars (retraction or expansion) was measured as per NBR 15261 (ABNT, 2005 [27]). $25 \times 25 \times 250 \mathrm{~mm}^{3}$ specimens were prepared containing pins at their ends used to place the specimen in the measuring equipment with a resolution of $0.001 \mathrm{~mm}$.

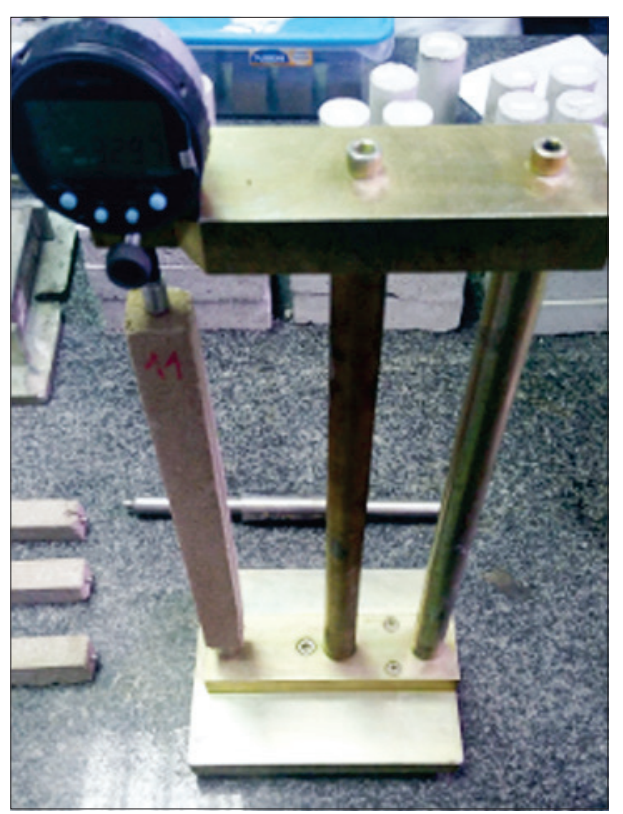

\section{Figure 2}

Equipment used for measuring the length of mortar bars 


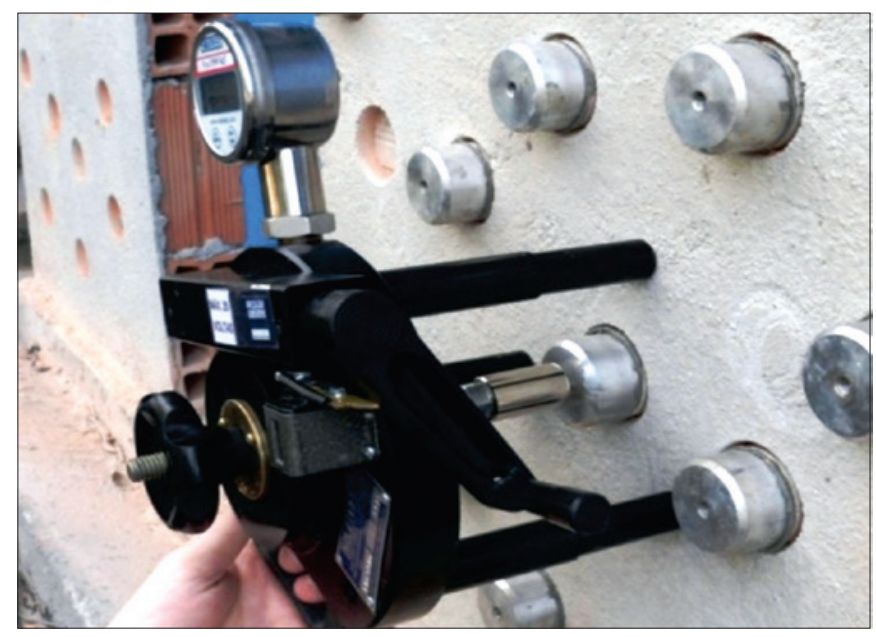

\section{Figure 3}

Equipment used in the test of tensile strength in the mortars bonding

The molding was performed in two layers, applying 25 strokes per layer, to obtain a homogeneous specimen. The specimens remained in the mold for 48 hours covered with PVC film. After deforming, the length readings were performed at 1,7 and 28 days (Figure 2). The dimensional variation was calculated by equation 5 .

$\varepsilon_{i}=\frac{L_{i}-L_{0}}{0.25}$

Where: $\varepsilon_{\mathrm{i}}$ is the measure of dimensional variation, characterized as retraction (when negative) or expansion (when positive), in age " $\mathrm{i}$ ", in $\mathrm{mm} / \mathrm{m}$; $\mathrm{L}_{\mathrm{i}}$ is the reading taken at the final age, in $\mathrm{mm} ; \mathrm{L}_{0}$ is the reading after deformation, in $\mathrm{mm}$; " $\mathrm{i}$ " is the reading age.

The compressive strength of the mortar was calculated as per NBR 13279 (ABNT, 2005c [28]). After the preparation of the mortar, specimens of $40 \times 40 \times 160 \mathrm{~mm}^{3}$ were molded. The mold was filled in 2 layers, and each layer was submitted to 30 falls through the binder table by falling. The specimens were scratched with a metal ruler. The mortars remained in the mold for 48 hours and were then demoulded for compression at the age of 28 days.

The sulphates resistance test also followed the procedure described in the literature (Rodrigues, 2004 [29], ASTM, 2004 [30]), using 14 days aged dried specimens and successive $2 \mathrm{~h}$ immersion cycles in a sodium sulphate solution at $5 \%$ (125 g of sodium sulphate in $2.5 \mathrm{dm}^{3}$ of water). After each immersion, specimens were dried at $90 \pm 5^{\circ} \mathrm{C}$ for $21.5 \mathrm{~h}$ and then cooled for about 30 minutes, then the mass was measured. The $\mathrm{pH}$ solution (measured with a paper strip color indicator) remained constant at about 8 .

The tensile strength test of the mortars was performed as per NBR 13528 (ABNT, 2010 [31]). The equipment used in the tensile strength test was a digital traction dynamometer (Figure 3), which allows continuous load application. $50 \mathrm{~mm}$ diameter pastilles and glue based on epoxy resin of high adhesion were used, with a thickness of about $2 \mathrm{~mm}$. Two walls of approximately $1 \mathrm{~m}^{2}$ each of ceramic brick masonry were constructed for the traction adhesion test. The thickness of the coating was $15 \mathrm{~mm}$. Conventional mortar was used for laying the bricks of all walls. The two walls were prepared with a mortar base to improve the adhesion ratio 1: 4 (cement: coarse sand) and coated with conventional mortar and with a locally marketed stabilized mortar.

Table 5 summarizes the tests for the aggregate and for the mortars, citing the references, quantities and age of the used samples.

\section{Results and discussions}

\subsection{Characterization of fine aggregates}

The four selected sands were characterized to determine which would be best suited for use in stabilized mortar. The granulometric curve of the studied sands can be observed in Figure 4. The studied sand 1 was chosen to perform all the mixtures of this study, since it presented fineness modulus of 1.75 , close to 1.70 [19]. Sands 2, 3 and 4 are thinner than sand 1 . The calculated maximum diameter was $1.18 \mathrm{~mm}$ for all four sands.

Sand 1, selected for all mortars, has the highest specific mass,

\section{Table 5}

Experimental program and test methods

\begin{tabular}{|c|c|c|c|}
\hline Studied properties & Curing time (days) & Samples per test & Standard test method \\
\hline \multicolumn{4}{|c|}{ Fine agregate } \\
\hline Particle size analysis & 0 & 2 & NBR 248 (ABNT, 2003) \\
\hline Specific gravity & 0 & 2 & NBR NM 52 (ABNT, 2009) \\
\hline \multicolumn{4}{|c|}{ Mortar } \\
\hline Preparation of mortar & 0 & - & NBR 16541 (ABNT, 2016a) \\
\hline Consistency index & 0 & 3 & NBR 13276 (ABNT, 2016b) \\
\hline Specific gravity and the air entrained content & 0 & 2 & NBR 13278 (ABNT, 2005b) \\
\hline Water retentivity & 0 & 2 & NBR 13277 (ABNT, 2005a) \\
\hline Setting time & 0 & 2 & By calorimetry \\
\hline Dimensional charges (shrinkage) & 1,7 and 28 & 2 & NBR 15261 (ABNT, 2005) \\
\hline Compressive strength & 28 & 6 & NBR 13279 (ABNT, 2005c) \\
\hline Attack by sulphates & 14 & 2 & $\begin{array}{c}\text { ASTM C } 1012 \text { (ASTM, 2004), } \\
\text { and Rodrigues (2004) }\end{array}$ \\
\hline Tensile strength in bonding & 28 & 12 & NBR 13528 (ABNT, 2010) \\
\hline
\end{tabular}




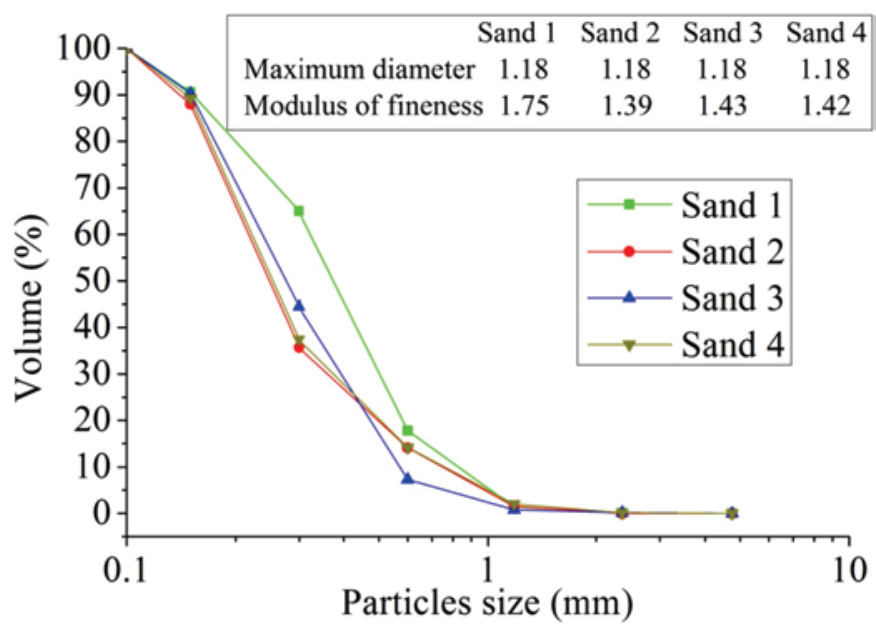

Figure 4

Particle size analysis of the studied sands

equal to $2.23 \mathrm{~g} / \mathrm{cm}^{3}$. Sand 2 presented $1.93 \mathrm{~g} / \mathrm{cm}^{3}$. Sand 3 and sand 4 presented $2.23 \mathrm{~g} / \mathrm{cm}^{3}$ and $2.05 \mathrm{~g} / \mathrm{cm}^{3}$, respectively.

\subsection{Consistency index of mortars}

Superplasticizers provide the possibility of better dispersion of cement particles, thereby producing paste of higher fluidity. With the development of high strength comes high performance (Chandra and Björnström, 2002 [32]). Figure 5 presents the results of the consistency index after 30 minutes of mixing and also after 1 hour and 30 minutes of mixing.

It can be noted that the stabilized mortar 2 obtained the highest index of consistency. The stabilized mortars mixture 1 and 3 could be classified as dry, while conventional mortar and stabilized mixture 2 could be considered as plastic (Silva, 2008 [18]). Figure 6 shows the variation of the consistency indexes in percentage. Conventional mortar presented the greatest loss of consistency after 1 hour and 30 minutes, which is associated with its loss of workability. The presence of a handle retarder plasticizer additive ensured better stability in the workability of the mortar.

\subsection{Specific gravity and air entrained content of the mortars}

Table 6 shows the mass density in the fresh state of the studied mortars.

According Carasek (2010) [2], all mortars can be classified as normal (density between 1400 and $2300 \mathrm{~kg} / \mathrm{m}^{3}$ ). Conventional mortar was denser than stabilized mortar. Conventional mortar does not have high air entrained content because it has no ad-

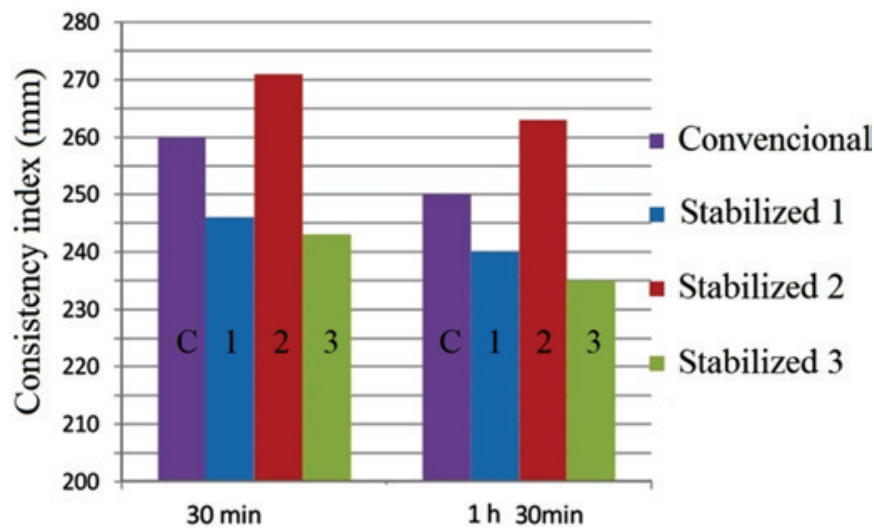

Figure 5

Results of the consistency index of mortars

ditives in its formulation. The stabilized mortar 3 had the highest content of incorporated air. The higher percentage of incorporator air implies a lower amount of water in the mixture, as the ratio between cement and sand of this mixture and the water cement factor is lower than that of other mortars. According to commercial traits, the value of air content incorporated for stabilized mortars should be above $22 \%$, because air loss is directly linked to loss of workability. Thus, the three stabilized mortars have adequate incorporated air content.

\subsection{Water retentivity}

Figure 7 shows the water retention index, in percentage, of the mortars. Water retention is the ability of fresh mortar to maintain its workability [2]. This means that the higher the water retention, the longer the hydration time, and the lower the water loss.

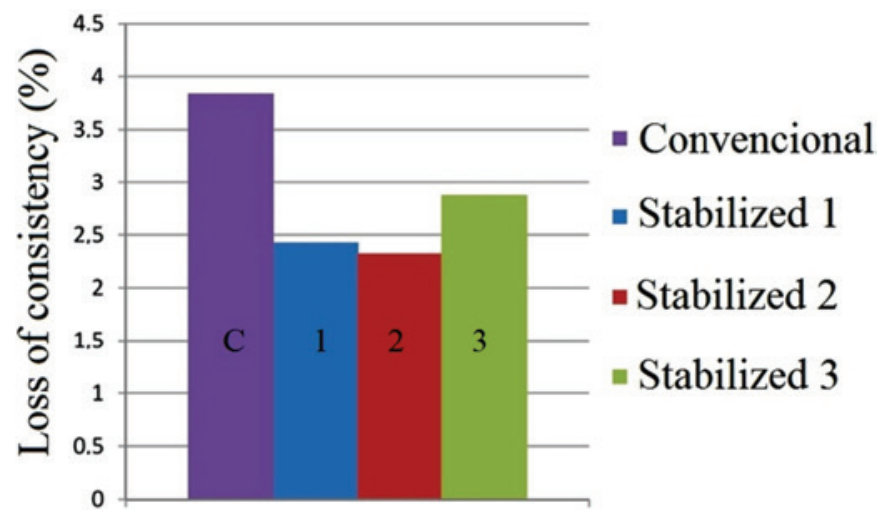

Figure 6

Variation of mortar consistency indexes in percentage

\section{Table 6}

Density of mass and incorporated air content in the fresh state of mortars

\begin{tabular}{ccccc}
\hline Mortars & Convencional & Stabilized 1 & Stabilized 2 & Stabilized 3 \\
\hline Density of mass $\left(\mathrm{kg} / \mathrm{m}^{3}\right)$ & 1727.9 & 1555.4 & 1647.2 & 1520.7 \\
Incorporated air content $(\%)$ & 12 & 24 & 22 & 29 \\
\hline
\end{tabular}




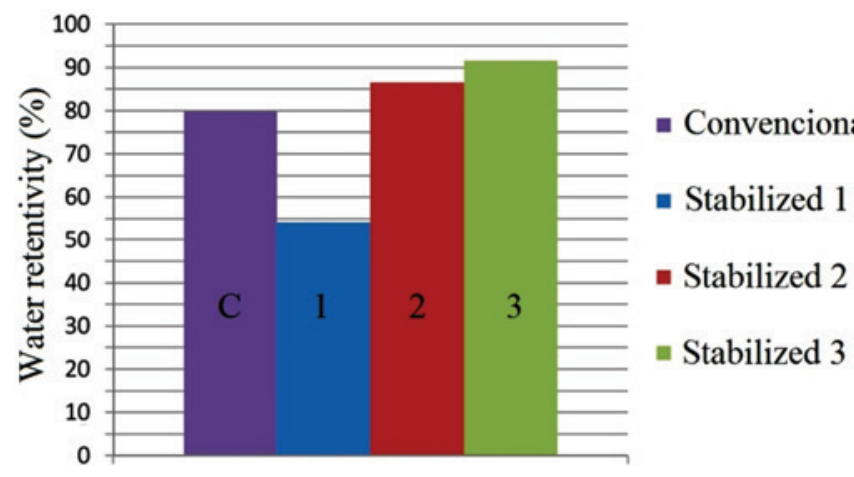

Figure 7

Water retentivity of the mortars

Thus, the greater the retention, the less the retraction effect, which cause cracks in the mortar in its hardened state.

Conventional mortar presented $71 \%$ water retention. The presence of lime in the conventional mortar was essential for water retention as it has the capacity to retain water around its particles. In stabilized mortars, the handle retarder additive delayed the hydration reaction of the cement particles. Thus, it was found that with the increase of handle retardant additive, water retention increased from stabilized mortar $1(54 \%)$ to $2(86 \%)$. Stabilized 1 had the largest water cement factor among the stabilized ones $(0.90)$, which influenced the low water retention. In the stabilized mortar 3 , the retention also remained high $(91 \%)$, because the dosage of this additive is directly related to the amount of cement in the mixture, which was proportionally larger in the stabilized mortar 3. ASTM C270-14a (2014) [33] presents the minimum value of $75 \%$ for water retention.

\subsection{Setting time of the mortars by cement hydration heat}

The calorimetry test is used to measure set time through the heat

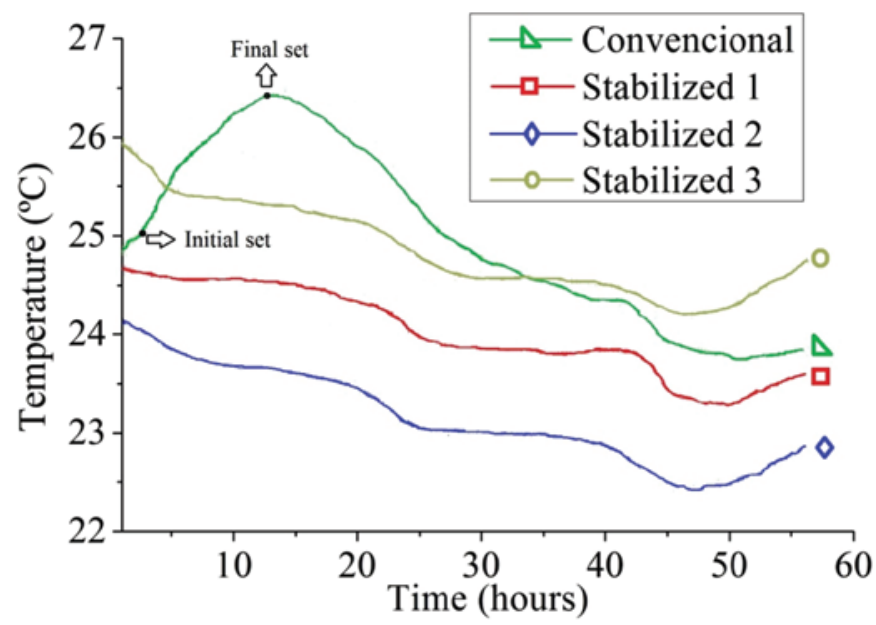

Figure 8

Water retentivity of the mortars flow of cement hydration (Qiao et al., 2012 [34], Hu et al., 2014 [35]). Concrete initial set is the time when cement hydration products, which initially surround individual cement particles, start to form a network which could correspond to the beginning of a rapid temperature rise in concrete that follows the dormant period (Mindess, 2003 [36], Metha and Monteiro, 2014 [37]). Concrete final set is the time when a primary network of hydration products is developed. The final set can be related to the time when concrete heat evolution reaches its maximum rate during the acceleration period, which corresponds to the approximate midpoint of the major peak hydration process (Mindess, 2003 [36]).

The use of polycarboxylate-based water reducing additives influences the setting time and heat of hydration of cement (Watts and Ferraro, 2017 [13]). The results obtained by the calorimeter tests can be seen in Figure 8.

Handle time is displayed in hours. The handle end was determined when the mortar presented the highest peak of the heat of hydration (maximum temperature reached) followed by a continuous drop. This point is well defined in the curve for the conventional mortar shown in Figure 8.

From Figure 8 , it can be noted that the beginning of the handle of the stabilized mortars was superior to the conventional mortar, and occurred after approximately 50 hours. The conventional mortar had its handle beginning in about 2 hours and was no longer workable quickly. This characteristic is also associated with the loss of consistency that was higher for conventional mortar.

Stabilized mortars 1 and 2 presented the best handle start results when compared to stabilized mortar 3 , which had a higher temperature. The handle time beginning is associated with the cement. It should be noted that these two mortars have 1:8 mixture, that is, a lower amount of cement in the paste than the stabilized mortar 3 (1: 6), which justifies this result.

The stabilized mortar 2 presented the lowest heat of hydration temperature, due to the higher percentage of handle retarder plasticizer additive. The stabilized mortars remained in the calorimeter with a layer of $1 \mathrm{~cm}$ of water on its surface in order to remain stabilized; As per the procedure carried out on site and indicated by the manufacturers.

The stabilized mortar 2 is not indicated for use, since the use of $1.5 \%$ of retardant additive was excessive, avoiding the complete hardening of the mortar, even after 96 hours.

\subsection{Dimensional changes of mortars}

One of the major problems that occurs while working with cementitious material is the excessive loss of moisture during cement hydration (setting and hardening), known as shrinkage, which provokes a great number of construction pathologies that are difficult to repair (Morón et al., 2017 [38], Nemirovsky and Eselev, 2009 [39]).

Curing age has an insignificant effect on the drying shrinkage. Drying shrinkage of mortar has a high correlation with the pore volume (Zhang et al., 2015 [6]).

A shrinkage reducing admixture (SRA) is another admixture traditionally used to reduce both autogenous and drying shrinkage of cementitious materials by reducing the surface tension of pore (Monosi et al., 2011 [40], Gedam et al., 2015 [41]). In this study, shrinkage reducing admixture was not used. 


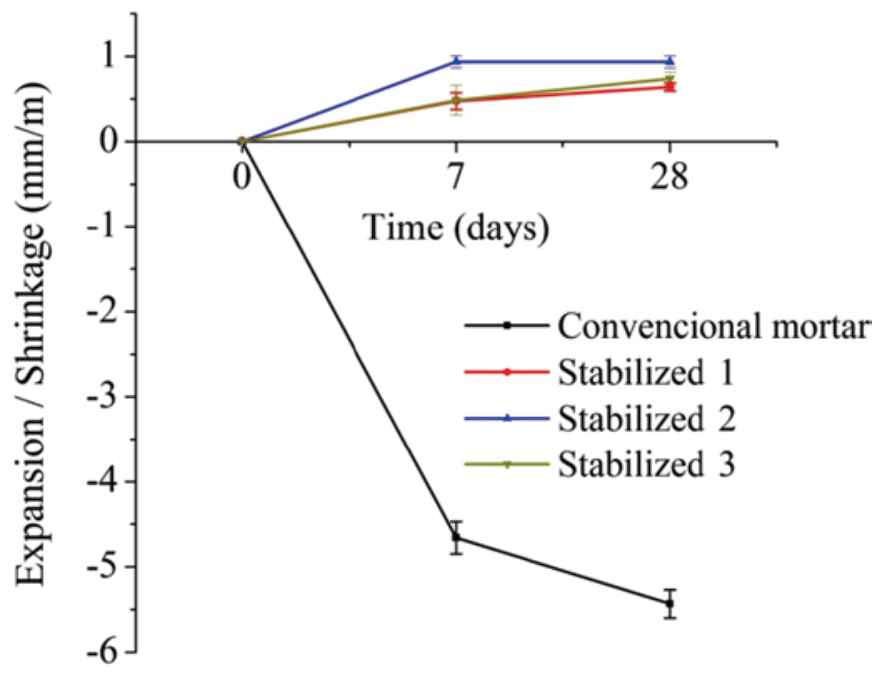

Figure 9

Dimensional variation of mortars.

Shrinkage (negative) and expansion (positive)

Figure 9 shows the results of the dimensional variation of the mortars. In the conventional mortar sample, retraction occurred, that is, its length decreased, while the samples of stabilized mortars expanded. The expansion in stabilized mortars may have occurred due to the air incorporator additive. The air incorporator in the fresh state may have influenced the modification of the structure of the cementitious matrix after its hardening. The use of a handle retardant additive may also have contributed to this expansion, since it slows the hardening of the mortar, reducing the hydration heat of the cement responsible for the retraction. The stabilized mor$\operatorname{tar} 2$, with the greatest amount of handle retarder additive (1.5\%), showed the greatest expansion.

Drying shrinkage is the dominant shrinkage in cement paste specimens. An abrupt increase in drying shrinkage was observed for all specimens as soon as the specimens were exposed to drying. Attention should be paid during this period to the prevention of shrinkage cracks (Kang and Sui, 2013 [42]). The higher amount of water in the standard mortar caused greater shrinkage by drying in this mortar.

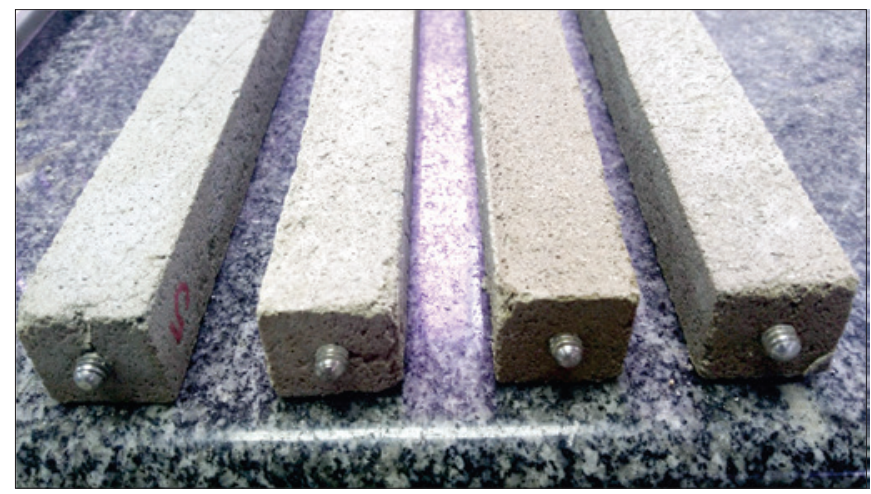

\section{Figure 10}

Some mortar bars used for analysis of dimensional variation
This little-known feature of stabilized mortars can be considered an advantage over conventional mortar. Other tests are recommended to confirm the expansion effect determined in this study. Figure 10 shows the appearance of the specimens used in the dimensional variation test.

\subsection{Compressive strength}

Figure 11 presents the compressive strength at 28 days of the mortars studied. The type and amount of additive, as well as the type of cement significantly influence the compressive strength of mortars. In an earlier study (Nagrockiene et al., 2013 [43]), the use of superplasticizer above $1.2 \%$ reduced the compressive strength of concrete.

A linear relationship is established between compressive strength and shrinkage; this correlation is more significant for the total shrinkage, and it is more adequate if the shrinkage is measured starting from the setting time (Itim et al., 2011 [5]).

From the data presented in Figure 11, it can be noted that the conventional mortar presented compressive strength (3.38 MPa) close to that of the stabilized mortar $1(2.91 \mathrm{MPa})$ and stabilized mortar 3 (2.92 MPa). The higher amount of handle retarder additive (apparently in excess) may have contributed to the sharp fall in compressive strength of stabilized mortar $2(1.02 \mathrm{MPa})$. The excess of additive caused excessive retardation of the hydration reaction of the cement and, thus, a significant decrease of resistance.

\subsection{Sulphate resistance}

Many studies attribute the expansion of mortars to alkali-silica reaction (ASR) (Pade and Struble, 2000 [44], Matos and Sousa-Coutinho, 2016 [45], Ghafoori and Najimi, 2016 [46]). The alkali-silica reaction (ASR) involves reactive siliceous minerals in aggregates and highly alkaline concrete pore solutions producing an expansive alkali-silicate gel, which can imbibe water and then expand (Wenk, 2008 [17]).

Figure 12 shows the evolution of the mass variation of the $4 \times 4 \times 16$ $\mathrm{cm}^{3}$ mortar samples submitted to attack by sulfate. Each wetting

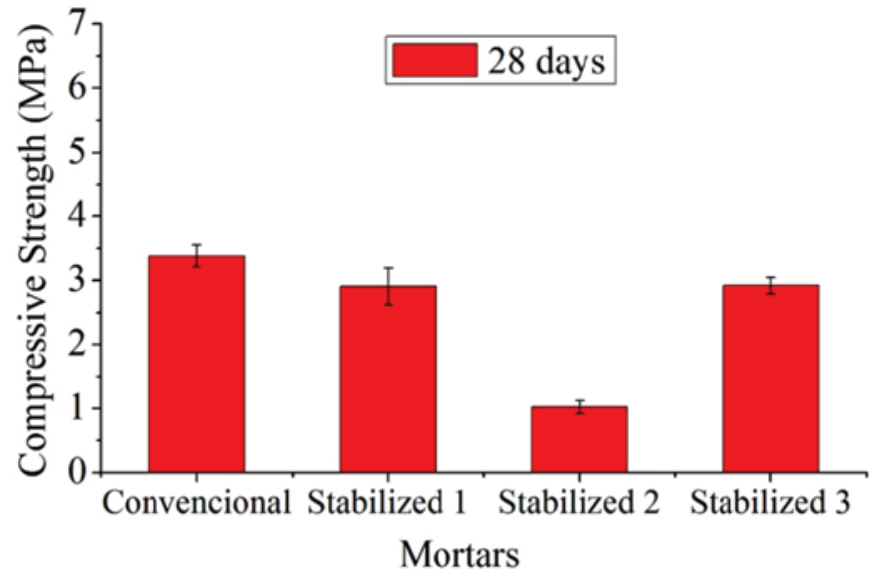

Figure 11

Compressive strength (CS) of mortars at 28 days 


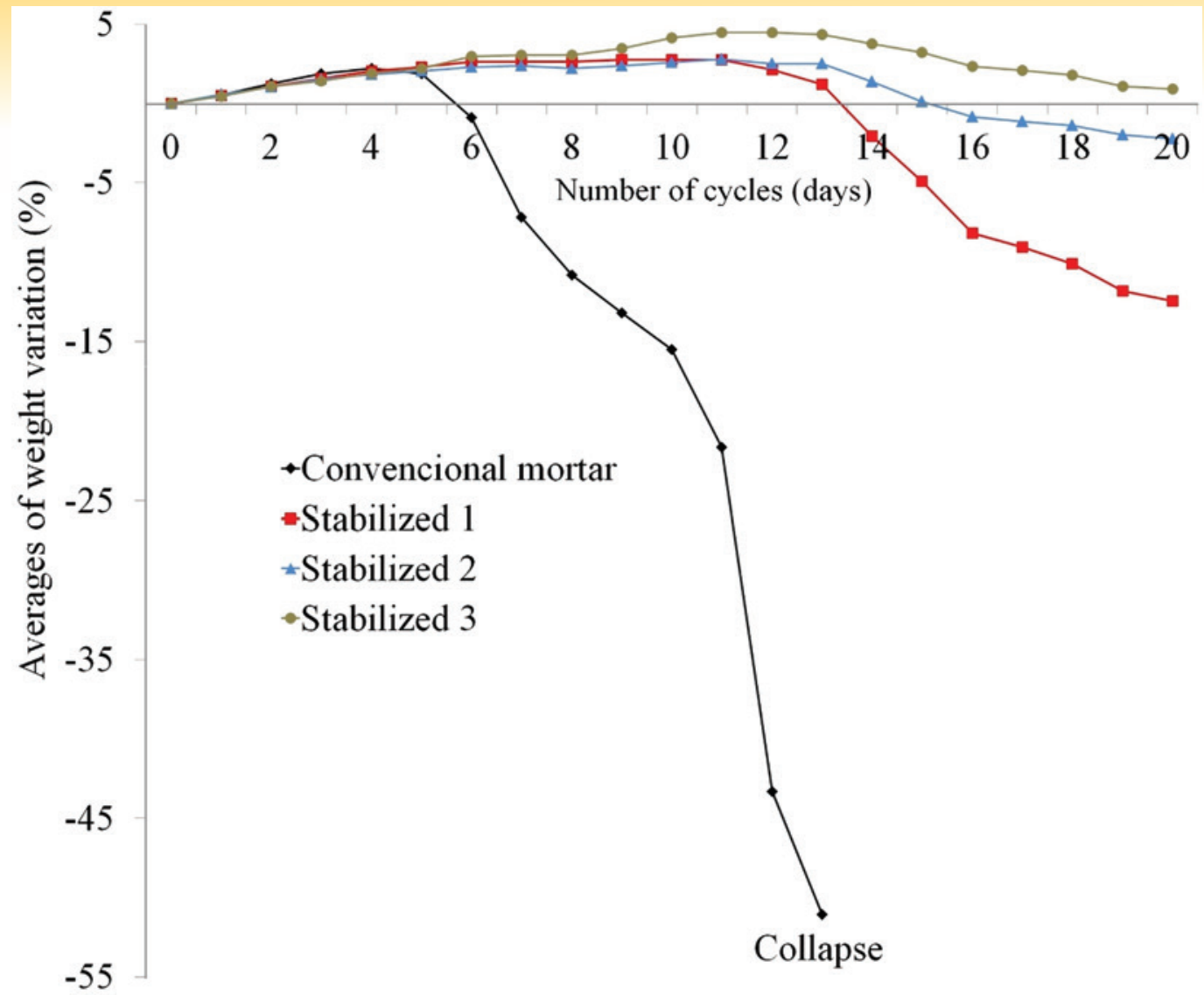

Figure 12

Results of the mass variation of mortar bars after sulphate attack

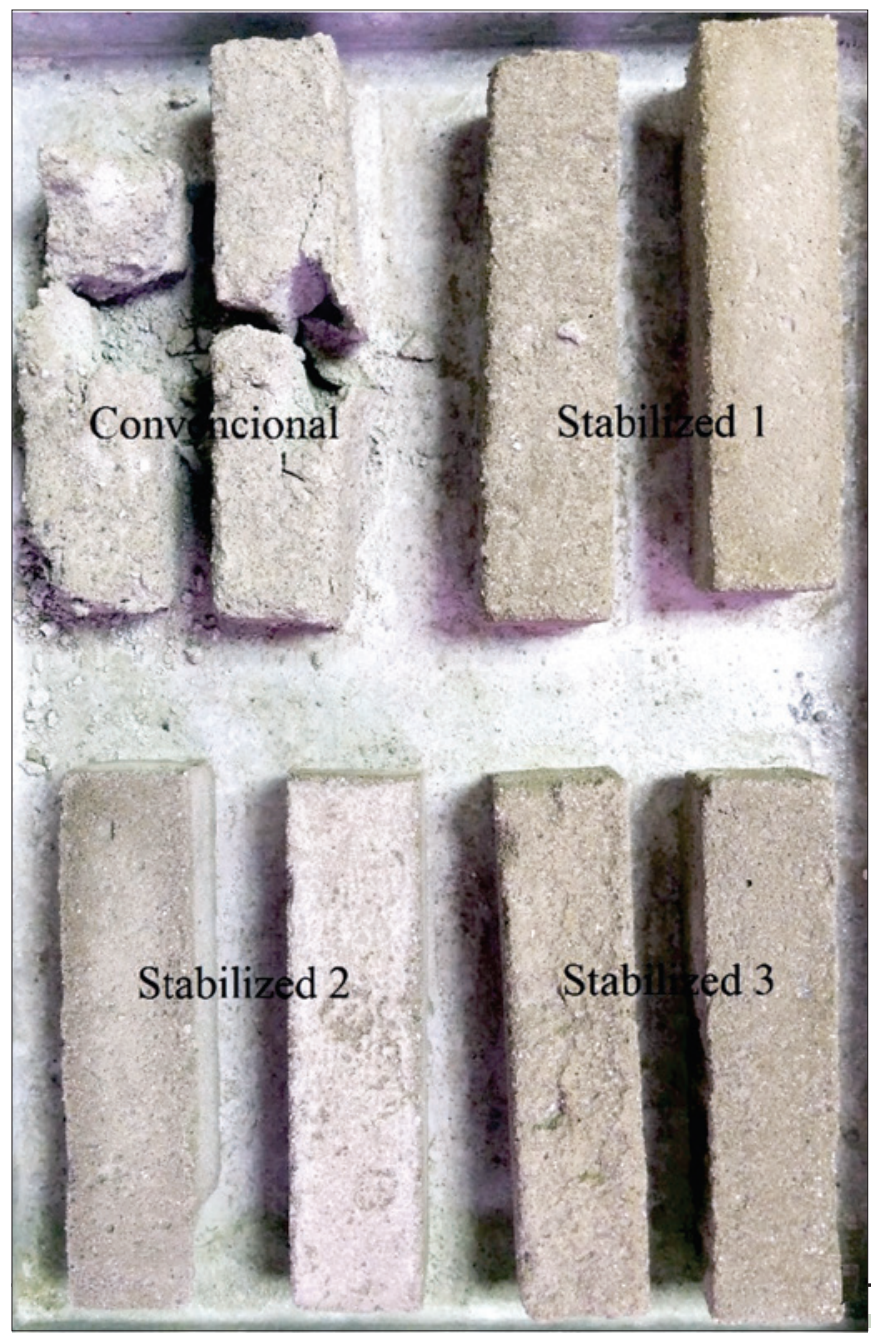

and drying cycle lasted 1 day. In cycle 13, the conventional mortar collapsed, clearly showing that this mortar has a lower resistance to sulfates in relation to stabilized mortars.

Figure 13 shows the appearance of mortars in the $12^{\text {th }}$ cycle. Among stabilized mortars, the stabilized 3 , which has a proportionately more cemented mixture, better withstand sulfate attack. The stabilized mortar 2 presented better resistance to sulphates than the stabilized mortar 1 . In figure 6 , it can be observed that the stabilized 2 showed the greatest expansion. This may have contributed to the sulfate having a larger space in the pores of the mortar to expand, thus taking longer to break the structure of the mortar by expansion.

\subsection{Tensile strength in bonding}

The tensile strength in bonding was found to be $0.48 \mathrm{MPa}$ for conventional mortar and $0.62 \mathrm{MPa}$ for stabilized mortar purchased commercially from a local company.

In conventional mortar, most of the disruptions occurred in the mortar itself and in the mortar/glue interface, indicating that the conventional mortar is inferior in quality to the commercially acquired stabilized mortar. In this commercial mortar, the rupture (in the tensile strength in bonding) did not occur in the mortar at all. It occurred only in the substrate/base for mortar bond, coarse mortar/mortar finishing and in the substrate itself indicating the best quality of the mortar.

Figure 14 presents three types of rupture in the mortar tensile strength in bonding test. There are still other types of disruption as per NBR 13528 (ABNT, 2010 [31]), but they did not occur in this study. 

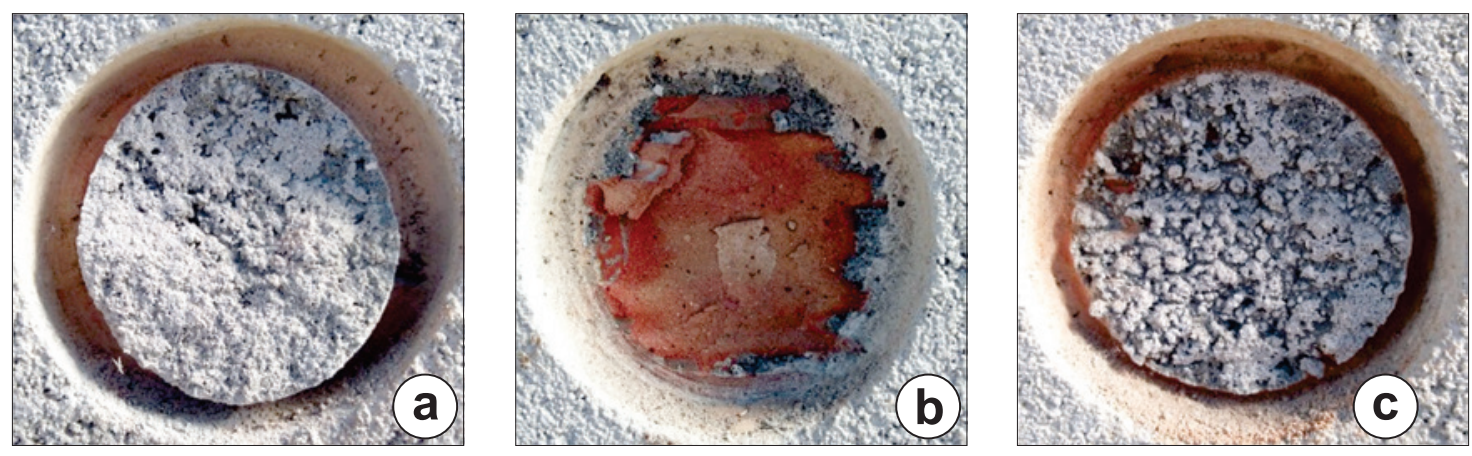

\section{Figure 14}

(a) Rupture in the mortar, (b) rupture in the substrate, (c) rupture in the interface mortar / base for mortar

\section{Conclusions}

We studied stabilized mortars for masonry laying with the use of air incorporator and handle retardant plasticizer additives and compared with a conventional lime mortar.

Among the sands studied, the most suitable for stabilized mortar has fineness modulus of 1.75 , fineness modulus of $1.18 \mathrm{~mm}$ and specific mass of $2.23 \mathrm{~g} / \mathrm{cm}^{3}$.

The presence of the settling retardant plasticizer affected the consistency index, making the mortar more workable for a longer time. The presence of additives made the stabilized mortars lighter, with lower mass density and higher incorporated air content. The lighter mortar, stabilized mortar 3, presented mass density of $1520.7 \mathrm{~kg} / \mathrm{m}^{3}$ and higher air content, $29 \%$. The more dense mortar, the conventional mortar, presented mass density of $1727.9 \mathrm{~kg} / \mathrm{m}^{3}$ and lower content of built air, of $12 \%$.

The presence of lime provided high water retentivity in the conventional mortar $(71 \%)$, while the setting retardant plasticizer improved the water retentivity in the stabilized mortars $(91 \%$ to stabilized 3).

The initial setting time of the stabilized mortars occurred after approximately 50 hours. Conventional mortar lost its workability quickly after 2 hours. This characteristic is also associated with the loss of consistency that was higher for conventional mortar (4\% after $1 \mathrm{~h}$ and $30 \mathrm{~min}$ ).

Shrinkage occurred in conventional mortar, while stabilized mortars expanded.

The conventional mortar exhibited better compressive strength (3.38 MPa). The stabilized 3 reached 2.92 MPa. The excess of additives can affect negatively this property in the stabilized mortars.

Conventional mortar proved to be less resistant to sulphate attack compared with the stabilized mortars.

Tensile strength was better in the stabilized commercial mortar tested $(0.62 \mathrm{MPa})$, than in the conventional mortar (0.48 MPa).

The stabilized mortar 2 is not indicated for use, since the use of $1.5 \%$ of retardant additive was excessive, avoiding the complete hardening of the mortar, even after 96 hours. The stabilized mortar 3 is the most indicated as it presented the best results among the mortars studied.

\section{References}

[1] Schmid AG. Stabilized mortar, an important tool for improving sustainability in construction. 53rd Brazilian Congress of concrete, Florianópolis, Brazil, 2011.

[2] Carasek $\mathrm{H}$. Civil construction materials and materials science and engineering principles. Isaia GC (Organizer/Editor) 2ed. São Paulo, IBRACON, 1v., 2010.

[3] Paulo RSVMN. Characterization of industrial mortars. Dissertation (Master in Environmental Management, Valorization of Materials and Waste), Aveiro University, Portugal, 2006.

[4] Macioski G. Evaluation of the behavior of stabilized mortars for coating. Undergraduate thesis (Civil Engineering undergraduate course), Federal University of Paraná, Curitiba, Brazil, 2014.

[5] Itim A, Ezziane K, Kadri El-H. Compressive strength and shrinkage of mortar containing various amounts of mineral additions. Construction and Building Materials, v. 25, 2011; p. 3603-3609.

[6] Zhang W, Hama Y, Na SH. Drying shrinkage and microstructure characteristics of mortar incorporating ground granulated blast furnace slag and shrinkage reducing admixture. Construction and building materials, v. 93, 2015; p. 267-277.

[7] Messan A, lenny P, Nectoux D. Free and restrained earlyage shrinkage of mortar: Influence of glass fiber, cellulose ether and EVA (ethylene-vinyl acetate). Cement and Concrete Composites, v. 33, 2011; p. 402-410.

[8] Cheah CB, Ramli M () Mechanical strength, durability and drying shrinkage of structural mortar containing HCWA as partial replacement of cement. Construction and Building Materials, v. 30, 2012; p. 320-329.

[9] Hasegawa Y, Choi M-K, Sato S, Natsuka I, Aoyama S. Characteristics of drying shrinkage in mortar using various industrial by-products as fine aggregate. 農業農村工学会論文集, v. 82,2014 ; p. 261-266.

[10] Fujiwara H, Maruoka M, Liu L. Development of spraying agent for reducing drying shrinkage of mortar. IOP Conference Series: Materials Science and Engineering, IOP Publishing, 2017, p. 012061. 
[11] Pytel Z. Heat evolution in hydrated cementitious systems admixtured with different set controlling components. Journal of thermal analysis and calorimetry, v. 77, 2004; p. 159-164.

[12] Lootens D, Bentz DP. On the relation of setting and early-age strength development to porosity and hydration in cementbased materials. Cement and Concrete Composites, v. 68, 2016; p. 9-14.

[13] Watts BE, Ferraro C. Prediction of setting for admixture modified mortars using the VCCTL. Cement and Concrete Composites, v. 78, 2017; p. 63-72.

[14] Sant G, Dehadrai M, Bentz D, Lura P, Ferraris CF, Bullard JW, Weiss J. Detecting the fluid-to-solid transition in cement pastes. Concrete international, v. 31, 2009; p. 53-58.

[15] Neville AM. Properties of Concrete, 5th edition, Bookman, 2016.

[16] Zhang W, Zakaria M, Hama Y. Influence of aggregate materials characteristics on the drying shrinkage properties of mortar and concrete. Construction and Building Materials, v. 49, 2013; p. 500-510.

[17] Wenk H-R, Monteiro P, Shomglin J. Relationship between Aggregate Microstructure and Mortar Expansion. A Case Study of Deformed Granitic Rocks from the Santa Rosa Mylonite Zone. Journal of Materials Science, 43, 2008; $p$. 1278-285.

[18] Silva ASR. Mortars: concept, types and functions, class presentation, Federal University of Bahia. Polytechnic school, Salvador, Brazil, 2008.

[19] Hermann, A; Rocha, JPA. Feasibility study of the use of modified stabilized mortar for coating without rough cast. Undergraduate thesis (Civil Engineering undergraduate course), Federal Technological University of Paraná, UTFPR. Pato Branco, 2013.

[20] Keller, HA .; Lovato, PS. Evaluation of properties of mortars stabilized over time after preparation. In: National Meeting of Technology of the Environment Built, 16, São Paulo, ANTAC, 2016.

[21] ABNT, Brazilian Association for Technical Standards. NBR 248. Aggregates - Sieve analysis of fine and coarse aggregates. Rio de Janeiro, Brazil, 2003.

[22] ABNT, Brazilian Association for Technical Standards. NM 52. Fine aggregate - Determination of the bulk specific gravity and apparent specific gravity. Rio de Janeiro, Brazil, 2009.

[23] ABNT, Brazilian Association for Technical Standards. NBR 16541. Mortars applied on walls and ceilings - Preparation of mortar mixture for tests. Rio de Janeiro, Brazil, 2016a.

[24] ABNT, Brazilian Association for Technical Standards. NBR 13276. Mortars applied on walls and ceilings - Determination of the consistency index. Rio de Janeiro, Brazil, 2016b.

[25] ABNT, Brazilian Association for Technical Standards. NBR 13278. Mortars applied on walls and ceilings - Determination of the specific gravity and the air entrained content in the fresh stage. Rio de Janeiro, Brazil, 2005b.

[26] ABNT, Brazilian Association for Technical Standards. NBR 13277. Mortars applied on walls and ceilings - Determination of the water retentivity. Rio de Janeiro, Brazil, 2005a.

[27] ABNT, Brazilian Association for Technical Standards. NBR 15261. Mortars applied on walls and ceilings - Determination of dimensional charges (shrinkage). Rio de Janeiro, Brazil, 2005.

[28] ABNT, Brazilian Association for Technical Standards. NBR 13279. Mortars applied on walls and ceilings - Determination of the flexural and the compressive strength in the hardened stage. Rio de Janeiro, Brazil, 2005c.

[29] Rodrigues MPSFF. Mortars for old masonies renders. The influence of binders. Doctoral Thesis, Nova University of Lisbon. Center for Science and Technology. Department of Civil Engineering, Lisbon, Portugal, 2004.

[30] ASTM, ASTM C 1012. Standard Test Method for Length Change of Hydraulic-Cement Mortars Exposed to a Sulfate Solution, 2004

[31] ABNT, Brazilian Association for Technical Standards. NBR 13528. Render made of inorganic mortars applied on walls Determination of bond tensile bond strength. Rio de Janeiro, Brazil, 2010.

[32] Chandra S, Björnström J. Influence of cement and superplasticizers type and dosage on the fluidity of cement mortars - Part I. Cement and Concrete Research, v. 32, 2002; p. 1605-1611.

[33] ASTM, ASTM C270 - 14a. Standard Specification for Mortar for Unit Masonry. 2014.

[34] Qiao F, Chau C, Li Z. Calorimetric study of magnesium potassium phosphate cement. Materials and structures v. 45 , 2012; p. 447-456.

[35] Hu J, Ge Z, Wang K. Influence of cement fineness and water-to-cement ratio on mortar early-age heat of hydration and set times. Construction and Building Materials, v. 50, 2014; p. 657-663.

[36] Mindess S, Young JF, Darwin D. Concrete, 2nd ed., Prentice Hall, Upper Saddle River, NJ., 2003.

[37] Metha KP, Monteiro PJM. Concrete Microstructure, Properties, and Materials. Third Edition. McGraw-Hill. University of California at Berkeley, 2014.

[38] Morón C, Saiz P, Ferrández D, García-Fuentevilla L. New system of shrinkage measurement through cement mortars drying. Sensors, v. 17, 2017; p. 522.

[39] Nemirovsky B, Eselev A. Effect of masonry mortar shrinkage on the linings impermeability. Polymer Science Series $D$, v. 2, 2009; p. 109-111.

[40] Monosi S, Troli R, Favoni O, Tittarelli F. Effect of SRA on the expansive behaviour of mortars based on sulphoaluminate agent. Cement and Concrete Composites, v. 33, 2011; p. 485-489.

[41] Gedam BA, Bhandari N, Upadhyay A. Influence of supplementary cementitious materials on shrinkage, creep, and durability of high-performance concrete. Journal of Materials in Civil Engineering, v. 28, 2015; p. 04015173.

[42] Kang J, Sui C. Influences of a composite addition on the strength of mortar and shrinkage of cement paste. Magazine of Concrete Research, v. 65, 2013; p. 1315-1324.

[43] Nagrockiene D, Pundienè I, Kicaite A. The effect of cement type and plasticizer addition on concrete properties. Construction and building materials, v. 45, 2013; p. 324-331.

[44] Pade C, Struble LJ. Kinetics and microstructural changes associated with mortar expansion. Cement, Concrete and Aggregates, v. 22, 2000; p. 55-62. 
[45] Matos AM, Sousa-Coutinho J. ASR and sulphate performance of mortar containing industrial waste. Structural Concrete, v. 17, 2016; p. 84-95.

[46] Ghafoori N, Najimi M. Sulfate resistance of nanosilica and microsilica contained mortars. ACI Materials Journal, v. 113, 2016; p. 459-469. 